\title{
Lender of Last Resort and Bank Closure Policy
}

\author{
XAVIER FREIXAS \\ BRUNO M. PARIGI
}

\author{
CESIFO WORKING PAPER NO. 2286 \\ CATEgory 6: MONETARy Policy AND InTERnAtional FinANCE \\ APRIL 2008
}

Presented at CESifo Area Conference on Applied Microeconomics, March 2008

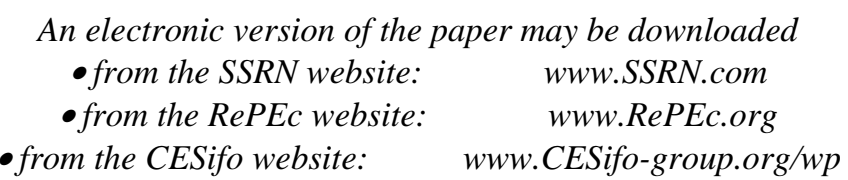




\title{
Lender of Last Resort and Bank Closure Policy
}

\begin{abstract}
During the last decades a consensus has emerged that it is impossible to disentangle liquidity shocks from solvency shocks. As a consequence the classical lender of last resort rules, as defined by Thornton and Bagehot, based on lending to solvent illiquid institutions appear illsuited to this environment. We summarize here the main contributions that have developed considering this new paradigm and discuss how institutional features relating to bank closure policy influences lender of last resort and other safety net issues. We devote particular emphasis to the analysis of systemic risk and contagion in banking and the role of the lender of last resort to prevent it.
\end{abstract}

JEL Code: E58.

Keywords: lender of last resort, systemic risk, contagion, bank closure, liquidity, discount window.

Xavier Freixas

Department of Economics and Business

University Pompeu Fabra

Jaume I Building

Ramon Trias Fargas, 25-27

08005-Barcelona

Spain

xavier.freixas@upf.edu

\author{
Bruno M. Parigi \\ Department of Economics \\ University of Padova \\ Via del Santo, 33 \\ 35123 Padova \\ Italy \\ brunomaria.parigi@unipd.it
}

February 8, 2008

We would like to thank the editors for their suggestions. We gratefully acknowledge funding from the Italian Ministry of University and Research, and jointly from the Italian and Spanish Ministries of University and Research through a grant Azioni Integrate/Accion Integradas 2006-7. 


\section{$\underline{1 . \text { Introduction }}$}

Since the creation of the first central banks (CB) in the XIXth century, the existence of a lender of last resort (LOLR) has been a key issue for the structure of the banking industry. The banking system has to provide mechanisms to manage banks' liquidity risk because one of the major functions of banks is to offer access to the payment system and facilitate property rights transfer, and because it is efficient to combine these functions with opaque long term investments on the asset side (delegated monitoring) and with demand deposits on the liability side (as justified by Diamond, 1984, Diamond and Dybvig, 1983, Calomiris and Kahn, 1991, or Diamond and Rajan, 2001). Although in any developed economy, the principal mechanism to cope with both excesses and shortages of liquidity will be the interbank market, the well functioning of the banking system might still require an additional mechanism to avoid that both aggregate and bank specific liquidity risk mismanagement results in a bank defaulting on its contractual obligations. The terminology "of last resort" itself emphasizes that this institution is not intended to replace existing regular market mechanisms, but should make up for its possible, although infrequent, failures. This justifies the existence of a discount window in the US and the marginal lending facility in Europe.

The basic objective of lender of last resort lending were first formulated by Thornton (1802) and Bagehot (1873) who argued that it was necessary in order to support the whole financial system and to provide stable money growth (Humphrey, 1989). Since then, the role of the LOLR has become a more controversial issue. The debate is inherent to the fact that, by providing insolvent banks, with liquidity we are allowing them to escape market discipline, and promoting forbearance. Clearly, there is a consensus among academics and central bankers that a mechanism should exist to allow solvent banks to obtain liquidity if the interbank market fails to operate correctly. Also, everyone agrees that insolvent banks should not access the standard liquidity facilities and that, if necessary, their insolvency should be dealt with on a case by case basis. The problem arises because liquidity shocks affecting banks might be undistinguishable from solvency shocks. So, the debate 
about the role of the LOLR is connected to the efficient bank closure policy and, more generally, to the costs of bank failures and of the safety net.

This connection between the LOLR and bank bail-out policy is not yet fully accepted. This may be due to the fact that access to liquidity, as well as the role of the LOLR has evolved through history. Those accepting Bagehot's view of the LOLR may argue that it relates to a world where solvent banks were to be protected against sudden deposit withdrawals without the recourse of a well developed repo market and without the $\mathrm{CB}$ privilege of issuing fiat money. With the emergence of a well-functioning repo market, today's conception of the role of the LOLR is completely different. The LOLR may step in exceptionally to prevent a collapse of the payment system that could be triggered by the lack of liquidity, but this should normally be dealt with by means of the appropriate monetary policy. So, if the money markets are well-functioning, the LOLR should manage aggregate liquidity only and leave the issue of solvency to the market that will eliminate the lame ducks.

The critical step in this argument is the assumption of perfect money markets. Once we consider imperfect money markets we are forced to consider cases where it is impossible to distinguish whether a bank is solvent or insolvent. So, we have to acknowledge that in solvency cases the LOLR is sometimes acting to channel liquidity and therefore is improving the efficiency of the monetary policy framework, while in the second case it is part of the safety net and directly related to the overall regulatory framework. Therefore the design of an optimal LOLR mechanism has to take into account both the monetary framework and the banking regulation context.

Consequently, we argue that it would be erroneous to adopt a narrow definition of the LOLR, stating that its role should be limited to the provision of liquidity, while capital injections should be the Treasury responsibility. This would lead to a very simplistic analysis of the LOLR functions, as the complex decisions would be either ignored or handed over to the Treasury. In our view, such a narrow view of the LOLR would be simply confusing by creating an artificial separation between lending by the LOLR at no risk (but at a cost to other claimholders as uninsured 
depositors or the Deposit Insurance Company) and the closure or bail-out decision by the Treasury. In fact, it is not credible to think that a systemic, too-big-to fail institution needing the support of the LOLR might be denied it, and a conceptual framework that would lead to the opposite conclusion is suspect of oversimplification.

On the contrary the rigorous view of the LOLR that we take here has to be a broad one, encompassing the closure or bail-out decision defining the LOLR as an agency that has the faculty to extend credit to a financial institution unable to secure funds through the regular circuit. This definition omits any mention to the fact that the institution is illiquid or insolvent. Obviously, this does not preclude that a separation between LOLR and Treasury decisions might prove efficient. Yet, what it implies is that it has to be proven so. This broad definition has the additional benefit to also encompass the management of overall banking crises, which would be difficult to consider from the narrow perspective of pure liquidity provision.

Once we agree that the LOLR policy has to be part of the overall banking safety net, the interdependence of the different components of this safety net becomes clear. First, the existence or not of a deposit insurance system, as well documented in Santos (2006) limits the social cost of a bank's bankruptcy, and therefore, reduces the instances where a LOLR intervention will be required. Second, capital regulation reduces the probability of a bank in default being effectively insolvent, and so has a similar role in limiting the costly intervention of the LOLR. Third, the procedures to bail-out or liquidate a bank, determined by the legal and enforcement framework will determine the cost-benefit analysis of a LOLR intervention.

Obviously, the LOLR policy and its efficiency will depend upon the overall financial environment. When a liquid market for Certificates of Deposit (CDs), T-Bill and securitized loans, or even simply for the loans themselves exists, banks will only exceptionally encounter difficulties in coping with their liquidity shocks. Adopting a perspective of an all-embracing safety net does not mean that the safety net has to be the responsibility of a unique agent. Often several regulatory agencies interact, because different functions related to the well functioning of the safety net are 
allocated to different agents. It is quite reasonable to separate monetary policy from banking regulation, and the separation of the deposit insurance company from the $\mathrm{CB}$ makes the cost of deposit insurance more transparent. Also, the national jurisdiction of regulation makes cross border banking a joint responsibility for the home and host regulatory agencies. This implies that regulation will be the outcome of a game among different agents that may cooperate or may be facing conflicts.

Finally, as part of the financial environment, the regulatory structure will be crucial. In particular, LOLR functions are usually attributed to the $\mathrm{CB}$, while another institution, often the Deposit Insurance Company, is in charge of closure. So, how the two decisions are coordinated is clearly an issue to be considered.

The rest of the paper is structured as follows: in Section 2 we will examine the justification of LOLR lending in a simplified framework where only liquidity shocks arise. Then, Section 3 will consider contagion in the interbank market. Section 4 will be devoted to the case where liquidity shocks cannot be disentangled from solvency ones. Section 5 discusses the issues raised by the implementation and decentralization of the LOLR policy within the safety net. Section 6 concludes.

\section{Pure liquidity shocks}

As already mentioned, one of the major features of banks, and a justification of their existence, is that they combine assets with a long maturity with short-lived liabilities. As a consequence, an institution providing liquidity to the banking system has a key role in the well-functioning of the whole credit, deposit and payment system. We will study here what types of liquidity shocks might affect banks and how Emergency Liquidity Assistance (ELA) may help them cope with those shocks. Still, setting a framework that explains why banks may face liquidity risk does not mean that a LOLR should exist. First, it could be argued that monetary policy, jointly with peer monitoring could solve the problem. Second, even if a specific institution is required, a private 
LOLR without any privileged access to CB liquidity could provide liquidity to the banks that need it.

We will first examine the different models of pure liquidity shocks, then turn to the analysis of a pure liquidity shock event, the disruption of the market as a result of the events of 9/11/2001, and close this section by discussing the pros and cons of a private LOLR based on the historical evidence.

\section{$\underline{\text { 2.1 Maturities transformation }}$}

The main motivation for LOLR in a modern economy is the need to prevent the threat of systemic risk whereby the crisis of one financial institution may affect others. In turn, the fragility of individual financial institutions stems from the very notion of the "fractional reserve system" where short term deposits finance illiquid long term investments.

The classical models of Bryant (1980) and Diamond and Dybvig (1983) show that a bank that offers demand deposits, invests the proceeds in illiquid assets, and keeps an amount of liquidity equal to the expected value of the liquidity needs of its depositors, can offer a valuable insurance function to consumers who are uncertain about the time of their consumption needs. However, the transformation of maturities exposes the bank to threat of bank runs if a large number of depositors decide to withdraw their money for reasons other than liquidity.

In this approach there are two possible equilibria. In the efficient one depositors withdraw only to satisfy their interim consumption needs thus allowing the illiquid investment to mature. But given that the value of bank assets does not cover the contractual obligations of the bank with its depositors at the interim stage there is also an inefficient equilibrium, where it is optimal for all depositors to withdraw early (a run), even for those that have no immediate consumption needs. This may cause the "fire sale" of long term or illiquid assets. Although deposit insurance and prudential regulation have essentially confined bank runs to text book phenomena they have not 
completely disappeared even in sophisticated banking systems, witness the run on the deposits of the mortgage lender Northern Rock in 2007, the first such event in Britain since 1866.

The traditional way to address equilibrium selection is to imagine that depositors behave in a way or in another depending on an exogenous event (a "sunspot" in the jargon of this literature). Since in one equilibrium banks increase welfare and in the other they decrease welfare, the impossibility to establish which equilibrium will prevail makes it impossible to determine whether it is ex ante desirable that banks arise as providers of inter temporal consumption insurance. In other words it is not clear why consumers would find it optimal to deposit their money in a bank in the first place. As a consequence, absent regulatory safeguards, policy recommendations are based on the assumption that a particular equilibrium will prevail, an issue that more recent modelling approaches using global games is not faced with as we will see in the sequel. Despite this shortcoming, the Bryant, Diamond-Dybvig approach has been the modern draught-horse for the study of financial instability and systemic risk. ${ }^{1}$

\subsection{Systemic risk}

Financially fragile intermediaries are exposed to the threat of systemic risk. Systemic risk may arise from the existence of a network of financial contracts from several types of operations: the payment system, the interbank market, and the market for derivatives. The tremendous growth experienced by these operations in the last decades increases the degree of interconnections among operators and among countries and thus the potential for contagion.

A number of papers have modelled contagion among banks and the ways to prevent it. The discussion will focus here on the two we consider most relevant. Allen-Gale (2000) show that

\footnotetext{
${ }^{1}$ One of the major features of the subprime crisis of 2007 , the fact that maturity transformation takes place off balance sheet, and therefore escapes banking regulation and the regulatory mechanisms to prevent runs, is to be considered also from this point of view: a liquidity crisis in a conduit or Special Purpose Vehicle, that is funded through a roll over of short term debt is akin from the point of view of liquidity to a holding bank with an unregulated subsidiary where bank runs can occur.
} 
financial contagion can emerge in a banking system of a multi-region economy. The interbank deposit market offers insurance against regional liquidity shocks but provides also a channel through which the shocks to the agents' preferences in one region can spread over other regions. Allen and Gale (2000) consider a version of the Diamond-Dybvig model with several regions in which the number of early consumers (the ones demanding liquidity at an interim stage) and late consumers fluctuate. An interbank market in deposits allows insurance as regions with liquidity surpluses provide it to regions with shortages. This constitutes an efficient mechanism provided there is enough aggregate liquidity. But if there is shortage of aggregate liquidity the interbank deposit market can turn into the channel through which a crisis spreads. Facing a liquidity crisis, before liquidating long term investments banks liquidate their deposits in other banks, a strategy that in the aggregate just cancels out. In case of shortage of aggregate liquidity the only way to increase consumption good early is eventually to liquidate long term investments. A financial crisis in one region can thus spread via contagion. Note that the nature of the crisis, and of the solution, is different with respect to the market for retail deposits as e.g. in the Diamond-Dybvig model. In the retail market runs occur because banks liquidate when they have insufficient liquidity to meet the fixed payment of the deposit contracts. Hence by making the contracts contingent or discretionary, incentive to run can be eliminated. In the interbank markets instead, the reciprocal nature of the deposit agreements makes these solutions impossible. Moreover, the likelihood that contagion happens depends on the architecture of the interbank deposits. If each region is connected with all the others the initial impact of the crisis can be attenuated and contagion avoided. On the contrary, if each region is connected with few others the impact of the initial crisis may be felt strongly on the neighbouring regions.

Using the notion that participants in financial markets may have different beliefs Castiglionesi (2007) extends the basic framework of Allen and Gale (2000) to ask if there is any instrument to avoid contagion. He argues that contagion is due to the impossibility to sign contingent contracts on unforeseen contingencies. This happens because the $\mathrm{CB}$ and market 
participants (banks and depositors) disagree on the prior of certain events; in particular they don't think that aggregate liquidity shortage is possible, hence they don't write contracts contingent on this event; the $\mathrm{CB}$ instead believes that with positive although small probability aggregate liquidity shortage is possible and can thus improve matters by imposing reserve requirements.

In Freixas, Parigi, Rochet (2000) (FPR) a system of interbank credit lines arises because depositors face uncertainty about where they need to consume. Financial connections reduce the cost of holding liquidity but make the banking system prone to experience speculative gridlocks even if all banks are solvent. The mechanism of the gridlock is the following: if the depositors in one location, wishing to consume in another location, believe that there will be not enough resources for their consumption at the location of destination, their best response is to withdraw their deposits at their home location. This triggers the early liquidation of the investment in the home location, which, by backward induction, makes it optimal for the depositors in other locations to do the same. The CB can play a role of crisis manager: when all banks are solvent the CB's role is simply to act as a coordinating device by guaranteeing credit lines of all banks. Since the guarantees are not used in equilibrium this action entails no cost. When instead one bank is insolvent because of poor returns on its investment the CB has a role in the closure of this bank, which has to be conducted in an orderly fashion to maintain the well-functioning of the payment network despite the closure of one bank.

Both Allen and Gale (2000) and FPR (2000) emphasize the key role the interbank market plays in propagating a crisis through the intertwining of their balance sheets, the default of one bank generating an immediate loss to all its unsecured creditors. Both emphasize that the structure of payments, with more or less diversification or more or less relationship lending will be a key characteristic of the resilience of the banking system. Yet, from a policy point of view the two models have a crucial difference. In Allen and Gale any CB emergency liquidity injection allows solving the crisis no matter where the liquidity is injected, as it is profitable for one liquidity long institution to lend to a liquidity short one. In FPR, since the crisis does not originate in an 
unpredicted liquidity shortage but in a rational alternative equilibrium strategy for depositors, injecting additional cash in the aggregate will not help. Even in the case where every bank has access to sufficient liquidity, the inefficient gridlock equilibrium exists where banks resources are used in an inefficient way. Solving the crisis in the FPR model is more the resort of the bank regulatory authority than of the $\mathrm{CB}$, as it requires guaranteeing that all claims on banks will be fulfilled. So, despite apparent similarities, the LOLR has a role of liquidity provider in the AllenGale model, while it has a role of crisis manager in the FPR one.

In a logic similar to the previous models another way in which the $\mathrm{CB}$ can prevent a crisis is to reallocate toward the correct risk the liquidity insurance of agents particularly sensitive to extreme events. Caballero and Krishnamurthy (2007) construct a model of the benefits of CB intervention during flight to quality episodes induced by such preferences. Agents deposit their wealth in financial intermediaries that insure them against shocks. Agents' preferences however, do not exhibit the traditional risk aversion characteristics. Rather, agents are uncertainty-averse in the sense that they are uncertain about the functioning of the economy. This is modelled assuming that agents maximize the minimum expected utility that they receive. In other words they are extremely sensitive to extreme events. Extreme events are modelled as repeated waves of shocks that induce the agents to demand liquidity. Each agent is concerned about the scenario in which he is the last one to receive a shock and there is little liquidity left. Since they all have max-min preferences this induces an upward bias in the probability of the worst case scenario. When aggregate liquidity is insufficient agents waste valuable liquidity by self-insuring against worst case scenarios which are impossible.

A CB with different preferences can improve matters. The $\mathrm{CB}$ has no more information than the private agents but just sees the world with a different lens, namely does not incorporate in its objective function the worst-case probability assessments of the private agents. Its objective function allows seeing the world from the aggregate which makes it apparent that the worst case 
scenario that all agents are guarding against is impossible. Thus CB policy works by reducing the agents" "anxiety" that they will receive a shock when liquidity is depleted.

\subsection{The LOLR and Liquidity shocks: the 9/11 case study.}

An important criticism on the classical view of the LOLR in today's financial market has been raised by Goodfriend and King (1988). They argue that, the existence of a fully collateralized repo market allows CBs to provide the adequate amount of liquidity which is then allocated by the interbank market. Since individual interventions would no longer be necessary the discount window is made obsolete. Well-informed participants to the interbank market are capable of distinguishing between illiquid and insolvent banks. These arguments have been so influential that the Bagehot view of the LOLR is often considered obsolete in well developed financial markets. Yet, Goodfriend and King's argument contradicts the asymmetric information assumption that is regarded as the main justification for financial intermediation. Goodfriend and King's argument is even less attractive if we consider Goodhart's (1987) criticism that liquidity and solvency shocks cannot be disentangled.

Here we will begin with the analysis of the conduct of the LOLR in a particular instance that offers a clear example of a system-wide liquidity shock. The liquidity effects of the events of September 11, 2001 illustrate well the systemic threats posed by the interdependencies in payment flows even in the absence of solvency shocks. McAndrews and Potter (2002) make the point that on September 11 banks experienced severe difficulties in making payments because of the widespread damage to the payments infrastructure. The nettable nature of payment flows allows banks to operate in the Fedwire system with an amount of reserves which is about $1 \%$ of their total daily payments, with the rest coming from the inflows of payments from other banks. This high velocity of circulation exposes the system to great risk if the normal coordination and synchronization of payments collapse as it happened on September 11. The events of that day resulted in an uneven distribution of liquidity in the banking system: while some banks unable to send payments 
accumulated higher-than desired balances, other banks' increased uncertainty about the flow of incoming payments led them to raise their precautionary demand for liquidity. McAndrews and Potter (2002) observe that the incident that triggered the liquidity shortfall was well known to all market participants and was generally perceived as a pure liquidity shock, unrelated to the fundamental solvency of any major financial institution. However, the fear of a systemic threat due to the breakdown of the coordination mechanism that banks use in their normal handling of payment flows induced the Fed to act. McAndrews and Potter (2002) and Coleman (2002) document that, on September 11 and in the following days the Fed took a number of steps to make sure that market participants would know that the Fed was ready to provide the liquidity that the market demanded. The Fed released a statement encouraging the banks to borrow from the discount window with the result that discount loans grew from $\$ 200$ million to $\$ 45$ billion on September 12; it waived daylight overdraft fees and overnight overdraft penalties so that overnight overdraft increased from an average of $\$ 9$ million in August 2001 to more than $\$ 4$ billion on September 12; later on, with markets beginning to function better the Fed increased liquidity in the interbank market via Open Market Operations (OMO) from $\$ 25$ billion to $\$ 100$ billion. The Fed did not simply inject liquidity; it also invited the banks to benefit from the discount window by lifting the stigma that is usually attached to this type of borrowing. Still, it could be argued that, had all the operations been channelled through the open market, the effect would have been the same. If so, it would be impossible to see if the liquidity crisis was of the Allen and Gale type or of the FPR type.

Nevertheless McAndrews and Potter (2002) point out another important lesson from these events that help discriminating between the two models. Banks that are reluctant to pay one another are also reluctant to lend one another. Thus in these circumstances injecting liquidity through OMO, as advocated for example by Goodfriend and King (1998) may be ineffective at redistributing balances because the additional funds may not be circulated where needed, contrary to discount 
window interventions. Only once coordination among banks has been re-established OMO may be preferred as they leave to the market the task to allocate liquidity.

That lending to the market via OMO may not be completely effective if banks are reluctant to lend to each other as they fear hidden losses in their counterparts balance sheets has been quite evident during the subprime crisis in the Summer of 2007. So, the subprime crisis is directly related to the solvency issue while the events of September 11 were the result of a pure liquidity shock.

To reinforce the previous point notice that the response of the Fed to the events of September 11, 2001 was facilitated by the fortuitous circumstance that the US banking system was in a relatively healthy condition at the onset of the crisis so that the Fed did not have to be selective about the account holders through which to channel reserves. Rather the Fed could lend freely to solvent banks according to the LOLR principles articulated by Bagehot, consistent with one of the missions of the Federal Reserve Act: "to furnish an elastic currency" (Lacker, 2004).

\section{$\underline{2.4 \text { Private LOLR }}$}

Although central banks and their LOLR functions are relatively new institutions, the financial history of the US before the creation of the Federal Reserve System in 1907 offers good examples of private arrangements to solve bank crises, namely the Commercial Bank Clearinghouses (CBCs) (See Gorton, 1985, and Gorton and Mullineaux, 1987 for a detailed analysis of CBCs). Originally developed to facilitate check clearance, the CBCs became organizations that performed a variety of tasks. During bank panics the CBC ceased to behave as an authority regulating competing banks and instead effectively combined the member banks into a single organization, with the group accepting corporate liability for the debts of each individual member. Among the most significant actions of the $\mathrm{CBC}$ during a bank panic were the suspension of the publication of individual banks balance sheet and the publication instead of aggregate balance sheet information for the clearinghouse as a whole, the suspension of convertibility of deposits into currency, and the issuance of loan certificates. Loan certificates were liabilities of the clearinghouse that member 
banks could use in the clearing process and could circulate as currency. These loan certificates, issued up to a fraction of the market value of the assets of the member bank seeking them, were in effect fiat money of the clearinghouse.

In the US, cooperation among banks produced stable interbank relationships, which in the case of the Suffolk system - an important example of a self-regulating bank clearing system operating throughout New England from the 1820s through the 1850s - were even more resilient than anticipated by their proponents (Calomiris, Khan, Kroszner, 1996). Many observers pointed out that the Federal Reserve System was a development of the existing CBCs (White, 1983, Gorton, 1985, Calomiris, Kahn, Kroszner, 1996, and Timberlake, 1978, 1993). However, one criticism of the functioning of the CBCs, was that their membership criteria were too stringent and designed to reflect only the interest of the member banks, not the public interest. For example the New York Clearing House Association demanded a very high level of reserves to qualify for membership so that many banks preferred to opt out of the clearing system (Sprague 1910). In the panic of 1907, a solvent Trust Company, the Knickerbocker Trust - which did not belong to any CBC - was forced to suspend as a result of liquidity problems. As argued by Friedman and Schwartz (1963, p.159) "Had the Knickerbocker been a member of the Clearing House, it probably would have been helped, and further crisis developments might thereby have been prevented." The consequence was one of the severest contractions in US economic history, and the impetus for the founding of the Federal Reserve System.

The example of the US CBCs shows that the financial linkages that expose banks to contagion threats may allow agents to obtain ex post mutual insurance in the form of private bail outs even though formal ex ante commitments are impossible. A recent study by Leitner (2005) provides a model that shows that linkages that create the threat of contagion may be optimal. Assume that the project of an agent can succeed only if he and the other agents whom he is linked to make a minimum level of investment. Since an agent's endowment is random he may not have enough resources to make the necessary investment. His inability to commit to repay may prevent 
him from borrowing against future cash flow or from entering an insurance contract ex ante. In the absence of contagion through financial linkages, agents with high endowments have no incentives ex post to lend to agents with low endowments; hence some positive net present value projects are not realized. But if agents are linked to one another, then those with high endowments have the incentive to bail out those with low endowments, because if they don't, all projects fail by contagion. Financial linkages, thus, can motivate banks to help one another even in cases in which they could not commit to do so ex ante. The consolidation of the balance sheets of the member banks of the $\mathrm{CBC}$ in crisis time, and the issuance of loan certificates drawn on the $\mathrm{CBC}$, by providing ex post mutual insurance, seem to have performed privately modern LOLR functions.

So, the evidence seems to indicate that, as expected, CBCs are more concerned about their own narrow interest than about the risk of contagion that may result from the bankruptcy of a bank outside their network. This is why a LOLR should have a mandate of preserving financial stability and should therefore encompass all banks not just the ones affiliated with its network. The question of semi-public institutions has not been the object of much research. Yet, during the subprime crisis of 2007 it has been argued that the Federal Home Loan Banks have massively lent to the banking industry and, by so doing, avoided an exacerbation of the mortgage crisis. ${ }^{2}$

\section{$\underline{\text { 3. Pure solvency contagion: the domino effect. }}$}

Although it is clear that systemic risk increases in situations of financial fragility, the issue of contagion is characteristic of the banking industry. The "domino effect" is the evocative term used to illustrate it, and with good reason. Banks are related to one another through a network of assets and liabilities, and a joint reputation. When considering the cost-benefit of a LOLR operation, contagion and systemic risk will be the first factors to be considered. Central banks have been clear

\footnotetext{
2 "FHLB advances rather than borrowing from the discount window reflects several factors: 1) the lower cost of FHLB advances, 2) the ability to borrow at longer terms from the FHLB, and 3) the lack of stigma in using FHLB advances as a source of funding." William Dudley, Executive VicePresident of the New York Fed, October 17, 2007, "May You Live in Interesting Times".
} 
in asserting that they will bail out banks that are systemic, thus comforting the market prevailing view that banks are not equally treated, as some banks are too-big-to-fail. The important issue is here to assess whether contagion is a myth or a reality.

From that perspective, it is important to start by reviewing the literature on contagion, and then point out some issues that affect the measure of contagion. Since the prevention of systemic risk is one of the main rationales behind the LOLR it is important to assess and quantify it. Unfortunately lack of data availability has limited so far the analysis. Researchers have thus resorted to study particular market segments or made particular assumptions about bilateral banks' exposures, and have concentrated on specific countries. Typically they take as given the failure of a bank and track its effects in the banking system. Although no general conclusions arise, most studies show that the failure of one bank may have significant knock-on effects on others, depending on the architecture of the interbank links, the concentration of the banking industry, the extent of cross-border banking, and the presence of de facto safety nets.

\section{1 Computing cross-banks contagion}

Humphrey (1986) was the first to investigate the extent of contagion by using data from the Clearinghouse Interbank Payments System (CHIPS). His simulation of the failure of a major participant in the payment system showed that this could lead to a cascading effect. More recently, estimates of contagion in the US federal funds market were obtained by Furfine (2003) that studied the particular segment of settlement data to compute bilateral exposures in the US federal funds market. He found that contagion is quite limited: even in the worst case scenario of the failure of the largest bank with a $40 \%$ loss given default, only between 2 and 6 banks fail with $0.8 \%$ of total bank assets involved. Since his data incorporate only federal funds transactions which account only for $10-20 \%$ of total interbank exposures the estimates of contagion are potentially conservative. However, illiquidity presents a greater threat: if a large federal funds debtor becomes unable to 
borrow, illiquidity could spread to banks representing almost $9 \%$ of the US banking system by assets.

Studies conducted for smaller economies and, or with a bigger size of cross-border transactions show a more pronounced risk of systemic repercussions. In particular Blavarg and Nimander (2002) study the impact that the failure of one of the top 4 largest Swedish banks may have on the rest of the system. They find that such a failure could push Tier 1 capital of the three other banks below 4\% and hence force their closure. An even more dramatic effect could result from the failure of the largest foreign counterparty.

Wells (2004) and Upper and Worms (2004) use a similar methodology to study contagion starting with estimates of the matrix of bilateral exposures of banks in the interbank market. However, since one can only observe each bank's total interbank claims and liabilities, it is not possible to estimate such a matrix without imposing further restrictions. Their approach is to choose a distribution that maximises the uncertainty (the "entropy") of these exposures. The result is that these exposures reflect the relative importance of each institution in the interbank market via the size of its total borrowing and lending. With this methodology Wells (2004) studies the effect of the sudden and unexpected insolvency of a single bank in the UK. He shows that this can lead to a substantial weakening in the capital holdings of other banks, but in most cases does not result in additional bank failures. By assuming complete loss given default, his model shows that, in the extreme cases, single bank insolvency could trigger knock-on effects leading in the worst case to the failure of up to one quarter of the UK banking system. At the same time, a further quarter of the banking system would suffer losses amounting to more than $10 \%$ of their Tier 1 capital. For loss given default levels of less than $50 \%$, contagion affects, at worst, less than $1 \%$ of total banking system assets. However, even with low losses given default, a narrow shock can considerably reduce the capital reserves of many banks. Furthermore, if the initial shocks hit during a period where the banking system is already weakened (e.g. during a recession), the effect of contagion can be more pronounced. 
Upper and Worms (2004) use German banks balance sheet information to estimate a matrix of bilateral credit exposures. They find that interbank lending is relatively concentrated and, as the theoretical literature suggests (Allen and Gale, 2000, and FPR, 2000) this makes contagion a real possibility. Despite the presence of institutional guarantees that prevent the failure of the savings and cooperative banks sector, there is considerable scope for contagion as the failure of a single bank could led to a break down of up to $15 \%$ of the banking system in terms of assets.

\section{$\underline{3.2 \text { Changing patterns in cross-bank contagion }}$}

Lack of data availability has forced previous researchers to conduct simulations based on bilateral exposures on a short period of time, while contagion risk has evolved over time as function of banking consolidation and the increased importance of cross-border banking. The availability of detailed confidential bank balance sheet data about Belgium allows Degryse and Nguyen (2006) to go beyond the existing literature on several respects. First using time series data on interbank exposures they examine the evolution over time of the contagion risk associated with the failure of a Belgian bank. Second, they conduct a regression analysis that identifies the major determinants of contagion. They find that a move from a "complete" structure - one where each bank lends to each other - towards a "multiple money centers" bank structure and the increase in concentration in the lending market decrease domestic contagion. They also find that an increase in the proportion of cross border assets decreases the risk and the impact of domestic contagion. These results contrast with those of Mistrulli (2005) for the Italian interbank market. He finds that the importance of cross-border exposures has decreased and that the transition from a "complete" toward a "multiple money centers" structure has increased contagion risk. Part of the contrasting results can be attributed to the different methodologies, as the Mistrulli's study is based on simulations while Degryse and Nguyen use regression analysis which allows sorting out the different sources of contagion. 


\subsection{An alternative approach}

The exposure of the LOLR to systemic risk can be quantified using standard risk management techniques that take into account the correlations between banks assets portfolios. While most studies take the probability of default as given and trace the impact of a bank default on the rest of the system, a new methodology proposed by Lehar (2005) allows estimating the probability of default and pricing the liabilities of the regulators with respect to the banks as contingent claims in the classic framework of Merton (1977). Assuming that bank assets values follows a geometric Brownian motion one can link equity price, asset values, and bank debt in a standard equation that sees equity (whose price is observable from the market) as a call option on bank's assets with a strike price equal to the notional value of bank debt (observable from the banks' balance sheet). Using a maximum likelihood estimation procedure the value of the banks' assets is then obtained and the exposure of the regulator computed. Lehar (2005) uses a sample of 149 international banks from 1988 to 2002 to identify the banks with the highest contributions to systemic risk and the countries which threaten the stability of the global financial system. Correlations of North American banks asset portfolios have increased but the systemic risk of the North American banking system has decreased over time as banks have increased their capitalization. Instead, the capitalization of the Japanese banks has declined dramatically causing that system to become very unstable. Not surprisingly the estimated regulator's liabilities increased sharply at the time of the Asian crisis in $1997 / 98$.

\section{$\underline{3.4 \text { Is contagion a myth? }}$}

On the basis of the previous estimates, one might be tempted to conclude that contagion is a myth. The exposures of banks one to another are limited and should not be a major concern for the regulator. But taking the estimates at their face value without considering the whole contributions that the theoretical models allow us to make would be an oversimplified view of contagion. From this point of view, at least three important criticisms should be formulated. They concern the 
indirect contagion through the behaviour of depositors, the business cycle, the price of bank assets during a crisis and the impact of liquidity.

First, the empirical evidence is based on the network of banks assets and liabilities. Still, it may well be the case that the failure of one bank implies contagion through demand depositors. Their rational updating of the chances of another bank of similar characteristics may lead them to withdraw their deposits in a fly for quality. Many banking crises illustrate this phenomenon, as during the Great Depression in the US, or in the ethnic bank crisis in the aftermath of the Bank of Credit and Commerce International in the UK. The default of the Madhavpura Mercantile Cooperative Bank in India in 2001 was used as a case study by Iyer and Peydro (2006) to examine the contagion taking place through demand deposits. Still, the overall analysis of the joint impact of a bank failure through the network of reciprocal liabilities and through depositor's reaction remains to be done.

The second remark is that the measure of contagion is different in good times and in bad times. The impact of an individual bank when the banking system is healthy is the object of the above analysis. Yet from the policy analysis point of view, it is not clear that this is the best measure of contagion. An individual bank is more likely to go bankrupt when all banks are in trouble. This, of course, makes the analysis much complex, because in such a case, contagioninduced and macroeconomic-induced systemic risk are simply undistinguishable. So, the new challenge in the measurement of contagion would be to try to compute the impact of a bank bankruptcy conditionally on the banking sector health, using some measure of the loan impairment in the banks' loan portfolio.

A third remark is the impact of a number of bank failures on the value of assets. The main impact, first identified by Irving Fisher (1933), concerns the price of assets that are used as collateral. In a debt-deflation situation, the value of assets decreases and this lowers the amount of collateralized loans, and therefore the amount of available credit, which, in turn, reduces output. This output declines will again impact into the price of assets, thus leading to a further reduction in 
asset prices until outside investors buy the assets (see also Kyotaki and Moore, 1997 and, more recently, Gorton and Huang, 2004, and Acharya and Yorulmazer, 2007).

Finally, and more tentatively, the cross-banks link could be underestimated as well if we restrict the analysis to solvency. In fact, a bank lending overnight to a peer financial institution that happens to be in default may not be fully satisfied with the knowledge that it will recover $95 \%$ of its claims in five years, after the liquidation of the failing institution is complete. This may trigger the lending bank to liquidate some of its assets later at "fire sale", possibly increasing the impact on the price of assets.

Recently the possibility of contagion from the asset side of interlinked balance sheets has received explicit attention in the literature. Acharya and Yorulmazer (2007) examine the efficient closure/bail-out policies and find out that if the number of banks facing distress is large enough, it may be ex-post optimal for the regulator to bail out some failed banks or alternatively to provide liquidity assistance to surviving banks in the purchase of failed banks. In both cases, the LOLR has to step in, as in Allen and Gale (2000) or FPR (2000). Schnabel and Shin (2004) and Cifuentes, Shin, and Ferrucci (2005) show that changes in asset prices may interact with solvency requirements or with internal risk control and amplify the initial shock. The idea is that the reduction of the value of a bank's balance sheet may force the sale of assets or the disposal of a trading position. If the assets market is not perfectly elastic, the sale of assets will induce a further decline in asset value which might outweigh the initial shock. The awareness of this risk is linked to a number of steps taken by the regulators to soften liquidity requirements in the face of crisis. Thus, for instance, the Financial Services Authority responded to the decline in stock prices in the Summer 2002 by diluting the solvency test for insurance companies and in 1998 the Fed orchestrated the rescue of the hedge fund LTCM to prevent the negative impact of asset values that would have resulted from the unwinding of its positions. 


\section{Distinguishing between insolvent and illiquid banks}

The difficulty to distinguish between an illiquid and an insolvent bank has been acknowledged at least since Bagehot's Lombard Street, when he argued "Every banker knows that if he has to prove that he is worthy of credit, however good may be his arguments, in fact his credit is gone". Modeling such a framework has been done only recently. Two different approaches are possible, one based on unobservable liquidity and solvency shocks and the other based on the coordination of interbank market lenders' strategic responses to fundamental, public and private, solvency signals.

\section{$\underline{4.1 \text { Unidentifiable shocks }}$}

The difficulty of sorting out liquidity and solvency shocks stems also from the unique position that banks have in creating aggregate liquidity. Diamond and Rajan (2005) - building on their previous work (Diamond and Rajan, 2001) - argue that banks perform two complementary functions: they have loan collection skills without which borrowers could not credibly commit to repay their loans, and they issue demand deposits to commit not to extract rents from investors. If a sufficiently large fraction of banks' portfolio needs refinancing (a solvency problem) the bank will be unable to borrow against its future value. But in that case there will be a shortage of liquidity in the economy to fund current consumption (a liquidity problem). A solvency problem or a liquidity problem alone can lead to a run on a bank if depositors anticipate losses. A run, in turn, destroys a bank's ability to extract money from borrowers and thus the ability to channel funds from surplus agents to those in need to consume. Thus after a run aggregate liquidity is destroyed (an effect not present in bank runs of the type of Diamond and Dybvig, 1983) and liquidity is also trapped in the wrong place; hence the difficulty of distinguishing between illiquid and insolvent banks. The appropriate policy response depends on the cause of the problem. When the source of the problem is a liquidity shortage Diamond and Rajan (2005) advocate to lend freely to prevent a drop in the money stock. When solvency is the problem their advice is to recapitalize banks. Recapitalization, however, can be harmful if the problem is lack of liquidity since capital infusion will simply push interest rates up 
potentially causing more bank failures. Liquidity infusion instead has the least downside and thus it fits the test of doing no harm.

The approach followed by Freixas, Parigi and Rochet (FPR) (2004) is also based on the impossibility of distinguishing illiquidity from insolvency. In their paper they consider that banks are confronted with shocks that may come from uncertain withdrawals by impatient consumers (liquidity shocks) or from losses on the long term investments that they have financed (solvency shocks) and that the two types of shocks cannot be disentangled. In acting as a LOLR the CB faces the possibility that an insolvent bank may pose as an illiquid one and borrow either from the interbank market or form the CB itself. Then the bank may "gamble for resurrection", that is, it may invest the loan in the continuation of a project with a negative expected net present value. This assumption is in line with the criticism of the LOLR during the S\&L crisis in the US during the eighties and justifies why CBs are reluctant to be more liberal in their use of ELA. This setting allows the authors to focus both on the incentive issues of ELA and under which macroeconomic conditions the $\mathrm{CB}$ should provide ELA, at the cost of abstracting from modelling contagion. In periods of crisis, when banks' assets are very risky, borrowing in the interbank market may impose a high penalty because of the high spread demanded on loans. FPR (2004) show that ELA should be made at a penalty rate so as to discourage insolvent banks from borrowing as if they were illiquid, but it should happen at a rate lower than the interbank market. The reason the $\mathrm{CB}$ can lend at better rate than the market is that the $\mathrm{CB}$ can lend collateralized and thus override the priority of existing claims. By penalizing insolvent banks that demand ELA, the CB provides banks with the appropriate incentives to exert effort to limit the probability that a bank becomes insolvent in the first place.

The implications of this approach can be clearly seen in the assessment of the 2007 international turmoil. The classical view of the interbank market, according to which the interbank market works perfectly, was that the spreads on interbank loans were understating risk, and that the observed turmoil was a correction in pricing on all assets and contracts that depended on the price 
of risk: real estate, mortgages and unsecured loans to banks. Instead, the FPR (2004) approach views the crisis as a joint one of liquidity and solvency, so that, absent $\mathrm{CB}$ intervention, the interbank market may exacerbate the adverse selection problems. Taking the argument to the extreme, as modelled, for instance, in Freixas and Holthausen (2005) or Freixas and Jorge (2007), this may lead to a thin market equilibrium as in the classical market for lemons. The policy implications are vital, since if the differential diagnostic is a correction back to the long term price of risk, the optimal policy may be for the $\mathrm{CB}$ not to intervene except in so far as to reduce the cost of banks failure. If, instead, adverse selection in the interbank market leads to a stand still, then the LOLR liquidity provision to individual institutions is capital.

\subsection{The global games approach}

Rochet and Vives (2004) provides a theoretical foundation of Bagehot's doctrine in a modern context. They shift the emphasis from maturity transformation and liquidity insurance of small depositors to the modern form of bank runs where large well informed depositors refuse to renew their credits in the interbank market. Building on the theory of global games they investigate the optimal behavior of bankers that observe noisy signals about banks' fundamentals. This allows obtaining a unique equilibrium, in contrast with the Diamond-Dybvig classical result. The global games approach overcomes the problem of equilibrium selection (Carlsson and Van Damme, 1993, and Morris and Shin, 1998) by linking the probability of occurrence of a crisis to both the fundamentals and the information of depositors. The proof of uniqueness of the equilibrium hinges of the assumption of global strategic complementarities, namely an agent's incentive to take an action increases monotonically with the number of agents who take the same action. Rochet and Vives (2004), Dasgupta (2004), Goldstein and Pauzner (2004), and Goldstein and Pauzner (2005), show the theoretical possibility of a solvent bank failing because agents withdraw their investments for fearing that others will. All these papers show that the introduction of noisy signals to multipleequilibria games may lead to a unique equilibrium. Since the signals are noisy, even a small 
asymmetry of information can lead to strategic uncertainty about the other agents' actions. This prevents the agents from coordinating their actions and reduces the set of possible equilibria. These models are panic based, that is, driven by bad expectations: depositors want to withdraw early because on the basis of their signal they fear that a sufficiently large number of other agents will withdraw. The beliefs of the investors are uniquely determined by the realization of the fundamentals in the sense that the fundamentals serve as a device coordinating agents' beliefs on a particular equilibrium. This approach allows reconciling two seemingly different views of banks runs: runs originated by negative real shocks, and runs originated by coordination failures.

Rochet and Vives (2004) apply this approach to the interbank market where, as a result of the signal a fraction of bankers decide to withdraw from other banks. A banker withdraws if and only if the probability of failure of the bank, conditional on the signal and the behavior of the other bankers, is large enough. This leads to the following equilibrium: if the signal about returns is poor bank failures are caused by insolvency; but if the signal about returns is good failures caused by illiquidity may still occur if many other bankers withdraw. The uniqueness of equilibrium and the fact that it is based on bank fundamentals allow Rochet and Vives (2004) to develop policy recommendations. Even if liquidity and solvency regulation can solve the coordination problem, Rochet and Vives (2004) show that the cost in terms of foregone investment is too large. Thus prudential measures must be complemented with LOLR interventions. CB interventions can be in the form of OMOs that lower the need to fire sale bank assets, or discount window lending. If the fire sale premium is high because of temporary liquidity crises then OMO may be preferred. Discount windows interventions may be instead preferred if the fire sale premium is thought to originate from an adverse selection problem. In either case the LOLR lending should be at below market rate in contrast with Bagehot's doctrine of lending at a penalty rate. 


\section{$\underline{\text { 5. Efficiency, regulators objective function, and decentralization }}$}

Although the characterisation of the optimal LOLR policy, as we have derived it in the previous section, brings a number of important insights, its implementation might be confronted with serious difficulties. First, the objective function of the regulator may be biased, not reflecting the correct values for the social costs and benefits of the continuation vs. liquidation decision. Second, the regulatory structure may be decentralized and therefore will combine decisions of two or more institutions with different objective functions. ${ }^{3}$ This decentralization may take different forms, depending on whether it is within a country, where a CB and a Deposit Insurance Company have to coordinate their policies, between monetary authorities and institutions in charge of prudential regulation (as the FSA in the UK), or between several countries as it is the case for multinational banks.

\section{$\underline{5.1 \text { A unique regulator }}$}

In order to analyse the bias in the regulator's objective function, consider first, as a benchmark, the decision of the regulator in the absence of a liquidity shortage. A distinction parallel to the one that is drawn regarding the autonomy of Central Banks may be here useful (Lybeck and Morris, 2004). A regulator is entrusted with Goal autonomy if it has the power to determine its primary objective from several objectives; it is entrusted with Target autonomy only if it has autonomy over one clearly defined primary objective, usually stipulated in the law. Absent moral hazard on behalf of the regulator, goal autonomy is preferred to target autonomy, because unrestricted welfare maximization obviously dominates the maximization of other objective functions. This could be the result of a tendency for the regulator to overestimate the cost of a liquidation or the benefits of the continuation, or more likely, could be the consequence of an incorrect objective function for the regulator in terms of its career, compensation and reputation, which, as stated in the classical Stigler 
(1971) and Peltzman (1976) "capture theory", might lead to collusion between regulator and the regulated bank.

Consequently, the effective comparison is not between restricted and unrestricted unbiased regulatory policies, but, rather between two second best policies: cost minimization, as a form of target autonomy, and welfare maximization, within a goal autonomy which is open to the regulator's discretionary interpretation and is, therefore, more sensitive to the biases in the regulator's objective function. In the US, the first approach has been selected: the regulatory choice has been to tie the regulator's hands by giving him a precise mandate of cost minimization.

Restricting the analysis to cost minimisation implies that the regulator's objective function is biased. This bias arises from the very fact that prudential regulation is concerned with downside risk only and disregards the upside potential for profits that the continuation policy may involve. Because of this, the cost minimizing LOLR will always be biased towards liquidation (Kahn and Santos, 2005). On the other hand, the regulator's own objective function may be biased towards overestimating the cost of liquidation and underestimating the cost of continuation and this will go in the opposite direction. In what follows we will survey the main results in the literature that makes the assumption of cost minimization. In the case of decentralization, this will imply that each regulator will consider only the costs that it has to bear, and not the total social cost.

A precision is here in order regarding the legal context. Although theoretically the regulator's mandate gives him the power to remove management and close down the bank, it may provide these options at very high costs (e.g. years of litigation) that the regulator may want to avoid. Two cases have to be considered: either these costs are limited and the regulator has the power to close down the bank independently of the liquidation shortage, or else, it is only when the bank is forced to resort to the LOLR that the regulator is able to decide whether the bank should be granted access

\footnotetext{
${ }^{3}$ Note that while the issue of the interplay between different regulatory instruments, as, for instance deposit insurance and banking supervision has been extensively examined, the interplay between different regulators has only recently been considered.
} 
to the LOLR facilities (and therefore will be able to continue its activity), or whether it should be denied it, in which case it would be closed down.

The case where the closure decision is to be taken in connection with a LOLR operation can be viewed, from a theoretical perspective, as the case where the regulator observes a non verifiable signal in a context where, for legal reasons, the decision to close down the bank cannot be based upon a non-verifiable signal. ${ }^{4}$ A bank faced with a liquidity shortage the interbank market that is not ready to cover, is forced to leave the continuation vs. closure decision in the hands of the CB. The lack of liquidity support from their peers, and the absence of liquid securities to pledge or sell also provide additional information that will allow the LOLR to update its information.

\section{$\underline{5.2 \text { Multiple domestic regulators }}$}

Decentralization between deposit insurance and LOLR has been initially analyzed by Repullo (2000) and then by Kahn and Santos (2005). With the trends towards the externalization of supervision and banking regulation outside the $\mathrm{CB}$, for instance in the hands of a Financial Services Authority, this issue is highly topical. From a theoretical point of view, the coordination of the two institutions should not be a problem as the two regulators compensation package could be optimally determined. Yet, in practice this is a clear issue, as both institutions may have different views regarding the costs and benefits of a loan to the defaulting institution. Although the total cost of a bank failure, whether cost of liquidation or reputation cost to the regulators could be shared, the positions regarding the effect of a loan are quite different and affect each institution incentives to intervene to rescue or to liquidate a defaulting institution. For the $\mathrm{CB}$, the cost of granting a loan is the amount of the loan, because, in the event of failure, part of the cost will be borne by the deposit insurance. On the other hand, from the point of view of the Deposit Insurance Company, the issue is

\footnotetext{
${ }^{4}$ Casual observation seems to indicate that regulatory authorities are quite reluctant to enter into a legal battle with a commercial bank that might end as a Pyrrhic victory. The case of BCCI where the Bank of England waited for almost a year before accumulating sufficient evidence of fraud prior to the coordinated closure of the institution across the world in July 1991 illustrates this point.
} 
continuation or liquidation rather than the cost of extending credit. This is so because the Deposit Insurance Company will take into account the cost of reimbursing all the insured deposits, not just the cost of the loan loss. As a consequence, both institutions may have opposite biases: the deposit insurance may be excessively prone to liquidation, because, as explained in the unique regulator case the regulator considers only downside risks, while the $\mathrm{CB}$, not bearing the full cost of paying back insured depositors may be bent towards continuation.

The allocation of power between the two regulators as well as their incentives will be capital in determining the type of LOLR policy. This issue might have played a key role in the Northern Rock crisis, and will therefore be at the forefront of the regulatory analysis in the forthcoming years. Two cases are to be considered depending on whether the agreement of the two institutions is necessary, or whether the allocation of the authority to close down a bank depends upon the extent of the liquidity shortage.

\section{Functional specialization}

When the mandates of the two regulatory agencies are clearly differentiated, the CB specializes in last resort lending while the Deposit Insurance Company is in charge of the continuation vs. closure decision. In this case, the two regulatory institutions have to agree on continuation, as otherwise the bank is closed down. In other words, a bank may be closed down either by the deposit insurance because of the signal on the bank future profitability, or else by the CB because of the excessive cost of the LOLR operation. So, because each regulator has a veto power, the joint decision reduces the forbearance problem (Kahn and Santos, 2005). Note that, again, the deposit insurance decision to close down the bank is biased towards excessive liquidation because it does not internalise the upper tail of the bank's profit, while the $\mathrm{CB}$ decision is also biased because the cost of a loan depends on its size; so for small loans the $\mathrm{CB}$ is prone to forbearance while for large ones it has a bias towards excessive liquidation that is even bigger than the Deposit Insurance Company's one. 
So, at high levels of illiquidity, the CB may refuse to lend despite the good signal the deposit insurance company receives on the bank's future profitability.

Regulatory powers allocated depending on the size of the liquidity shortage

Repullo (2000) considers an incomplete contract approach where both the CB and the deposit insurance are able to observe the same unverifiable signal on the bank future profitability, but where the right to act as the LOLR and therefore to take the decision as to whether the liquidity short bank should continue or should be closed down depends upon a verifiable variable, the amount of the required loan.

The main result of Repullo is that, if the CB is a junior creditor with respect to the deposit insurance, and if it lends at a zero interest rate, then it is optimal to allocate control to the CB when withdrawals are small and to the Deposit Insurance Company when they are large. As before, the intuition is based on the biases of the two regulatory institutions. For small loans the CB's decisions are closer to the optimal ones while for larger amounts, the Deposit Insurance Company's decisions are preferred. Contingent allocation on the basis of the realised liquidity needs lead, therefore, to an improvement with respect to the case where a unique regulator is in charge.

\section{Extending the framework}

Both Repullo (2000) and Kahn and Santos (2005) assume that the LOLR is a junior creditor. The reason for making this assumption is not that this is the most common structure, as frequently the $\mathrm{CB}$ is senior. The reason is simply that, if the $\mathrm{CB}$ has a senior claim and is certain to always recover the full amount of its loan, it has an incentive to systematically forbear. Thus, from a theoretical perspective, the issue of whether the loan should be collateralized or not, or, the closely related one of whether the CB should be senior is trivial: it reduces the cost of LOLR operations and therefore increases the tendency to forbearance. 
If there is a unique regulator, the regulator internalizes the cost that this generates on the deposit insurance company. This will then have an impact on uninsured claim holders that will see their probability of recovering the whole amount of their claim increase, while, at the same time, they will be confronted with a larger loss given default in case of liquidation. On the other hand, if the regulator is not unique, its seniority rights, or its use of collateralized loans will generate an externality on the deposit insurance fund. The LOLR operations will not be decided based on the real cost, but on the fraction of the cost that the $\mathrm{CB}$ incurs and this will lead to even a larger bias towards forbearance.

The functional specialization can be pushed one step forward if the Treasury is guaranteeing the loan of the $\mathrm{CB}$ to the illiquid (and may be insolvent) bank. In this case, the cost to the $\mathrm{CB}$ is only reputational. Such a scheme would parallel the one existing in the UK with the Bank of England lending with the guarantee of the Treasury. The mechanism has been used on September $17^{\text {th }}$ and then again on October $9^{\text {th }}, 2007$ to guarantee all the deposits at Northern Rock. The Repullo-KahnSantos approach predicts a CB that would be prone to excessive leniency.

In practice, we observe that $\mathrm{CBs}$ are quite reluctant to lend to financial institutions except against good collateral, thus following Bagehot's principles. Both the US Federal Reserve Discount Window and the ECB marginal lending facility operate on the basis of collateralized lending. Still there is a crucial difference between them: the ECB marginal lending facility collateral is based on securities traded in financial markets. So, it appears to be a substitute for a repo market with insufficient liquidity. On the other hand, under section 10B of the Federal Reserve Act, Reserve Banks can accept any assets satisfactory to them as collateral for discount window advances. ${ }^{5}$ So, the discount window mechanism cannot be considered a substitute for the repo market and allows to extent a larger amount of loans, possibly depriving the Deposit Insurance Company of valuable

\footnotetext{
${ }^{5}$ The Federal Reserve currently accepts a wide variety of instruments as collateral under section 10B, including customer notes, mortgages on one- to four-family homes, commercial real estate loans, credit card receivables, collateralized mortgage obligations, asset-backed securities, and a host of other common debt obligations (Board of Governors of the Federal Reserve System, 2002).
} 
assets in case of the bank bankruptcy. The same is true of the European marginal lending facility, which is open to a wider range of collateral than the weekly Main Refinancing Operations auctions, even if lending at a penalty.

\section{Information Gathering and information sharing}

Up to now we have assumed both regulators were endowed with an informative signal regarding the future profitability of the banks projects. In fact, one of the two regulatory agencies may have the informative signal and the question is whether it has incentives to share it with the other one. Kahn and Santos (2006) consider this issue. They show that when only the CB has access to information about the bank future profitability, it has no incentive to transmit this information. The implication is that when the costs for the deposit insurance are prohibitively high, the optimal institutional mechanism is to allocate the liquidation vs. closure power to the $\mathrm{CB}$ for small liquidity shocks, and to always support the bank's continuation for large liquidity shocks.

Although this statement may seem a bit extreme, it might nevertheless prove useful in the understanding of the Northern Rock crisis in 2007. The Bank of England considers that Northern Rock crisis is not systemic. Yet the market for liquidity dries. The FSA is in charge of solvency and issues a favourable report, confirming the "pure liquidity" assumption. The Bank of England cannot institute a mechanism similar to the ECB or to the discount window that allows for a much larger class of admissible collateral, and is therefore forced to resort to a special LOLR operation that guarantees all deposits. Without entering on the structure of deposit insurance in the UK or the fact that the actual terms and conditions of the credit facility are not public, the FSA had considered Northern Rock as following a safe banking strategy. ${ }^{6}$ The Bank of England had to rely on this information when choosing to extend a credit line. The difficulty of the Bank of England to avoid been perceived as encouraging moral hazard by not resisting to the lobbies of the uninsured debt

\footnotetext{
${ }^{6}$ On this it was not alone: Moody's in April 2007 and Standard and Poor's in August 2006 had raised Northern Rock rating by one notch.
} 
holders is clear in this case. Despite previous official statement to the contrary, the images of depositors lined up to withdraw from Northern Rock branches in the end forced the UK authorities to guarantee all depositors. Since, at the same time the credit line is guaranteed by HM-Treasury, the incentives to find information contradicting the FSA are quite narrow. The Northern Rock case illustrates the notion that assuming that the monetary authorities can always commit not to save lenders from their excesses is not realistic even in a sophisticated financial system. ${ }^{7}$

\section{Monetary policy and the LOLR}

One of the major achievements of theoretical and empirical research in the last two decades has been to establish that the independence of Central Banks in setting monetary policy is one of the conditions for economic stability. Still, when it comes to the independence of monetary policy and LOLR policy, the issue is more involved. To begin with, the LOLR policy is part of the safety net. So, a preliminary question would be to consider the pros and cons of having monetary policy and prudential regulation responsibilities delegated to two distinct institutions. The theoretical argument in favour of separation is the existence of possible conflicts of interest: as LOLR, the CB may feel compelled to bail out banks if this is necessary to prevent a systemic crisis. The conflict of interest is all the more serious in that monetary policy is countercyclical while prudential policy is procyclical, as bank bankruptcies occur in slowdowns (Goodhart and Schoenmaker, 1993). The

\footnotetext{
7 "The decision to authorise was made by the Chancellor on the basis of recommendations by the Governor of the Bank of England and the Chairman of the Financial Services Authority in accordance with the framework set out in the published Memorandum of Understanding between the Bank, FSA and HM Treasury." News Release, Bank of England, September 14th 2007. The Governor of the Bank of England, in his letter to the Treasury Committee on 12 September 2007 stated: "Central banks, in their traditional lender of last resort (LOLR) role, can lend "against good collateral at a penalty rate" to an individual bank facing temporary liquidity problems, but that is otherwise regarded as solvent. The rationale would be that the failure of such a bank would lead to serious economic damage, including to the customers of the bank. The moral hazard of an increase in risk-taking resulting from the provision of LOLR lending is reduced by making liquidity available only at a penalty rate. Such operations in this country are covered by the tripartite arrangements set out in the MOU between the Treasury, Financial Services Authority and the Bank of England. Because they are made to individual institutions, they are flexible with respect to type of collateral and term of the facility. LOLR operations remain in the armoury of all central banks."
} 
cross-country empirical analysis of Goodhart and Schoenmaker (1993 and 1995) establishes that central banks that have supervisory responsibilities experience higher inflation rates. On the other hand, Peek, Rosengren and Tootell (1999) empirical analysis show that information obtained from bank supervision helps the CB to conduct monetary policy more effectively. More recently, Ioannidou (2005) examining the behaviour of the three primary US federal regulators - the Federal Deposit Insurance Company (FDIC), the Office of the Comptroller of the Currency (OCC) and the Federal Reserve Board - shows that indicators of monetary policy do affect actions of the Federal Reserve Board, while it does not affect those of the FDIC or the OCC. Now, when we consider LOLR operations, the impact on monetary policy could, theoretically, be sterilized. ${ }^{8}$ So, when the bail out operation concerns an individual bank crisis, monetary policy should not be affected. Of course, when facing a generalized crisis, as in the case of the subprime crisis of 2007, the CB has to consider the impact of the banking crisis on expected growth and inflation patterns, and therefore is expected to intervene. ${ }^{9}$

In summary the empirical evidence indicates that whether the responsibilities of monetary policy and prudential regulation are joint or separated does affect the way they are implemented. Still, this does not tell us which of the two models, is more efficient.

An extreme version of the idea that the assets market is not perfectly elastic arises when not all assets can be used to purchase other assets. Gorton and Huang (2004) show that when there are such "liquidity-in-advance" constraints it is privately efficient for agents to hoard liquidity but it is not socially efficient given the opportunity cost of foregone investment opportunities. When the amount of the assets to be sold is so large that it would have been inefficient for private agents to have hoarded liquidity, the government can improve welfare by creating liquidity to bail out banks

\footnotetext{
${ }^{8}$ Although, as noted by Goodhart and Huang (1999), the residual uncertainty on the precise amount of the bail-out operation may have a macroeconomic impact.

${ }^{9}$ The type of interventions we have witnessed on behalf of the Fed and of the ECB show a different conception of the role of monetary policy in its interaction with a banking crisis. In particular, the reaction to stock market movements on January $21^{\text {th }}$ and $22^{\text {nd }} 2008$ reveal strikingly different views of the timing and frequency of money market interventions.
} 
by taxing solvent projects. The drawback is that if the government tax capacity is too small, the government cannot bail out all banks and forbearance arises. The link with monetary policy and the conflict of interest it implies is clear. Banking crises will materialize in a downturn, under a tight monetary policy. This puts pressure on the prices of assets, thus setting the stage for a debtdeflation. If, simultaneously, the LOLR has to bail out banks in distress, there is a clear case for coordination of policies and weighting of the cost of a higher inflation versus the cost of banking crises.

\section{$\underline{5.3 \text { Multiple international regulators }}$}

The previous analysis of multiple regulators can be extended to international regulatory bodies. If regulators internalize correctly the costs of bankruptcy, the Repullo-Kahn-Santos approach could lead to interesting insights. Regulators in different countries may have different signals, and so, may have different views on the continuation vs. liquidation decision. Still, there are additional complexities, because of the possibility to free ride on the subsidies provided by the other country. This issue constitutes one of the major challenges of banking regulation and is vital for the future of European Financial integration, where regulation of an institution could be in the hands of one institution while monetary policy in the hands of another and this asymmetry affects also the private and social costs of a bankruptcy. The classical textbook market imperfections of externalities and the provision of public goods are present here. When the major banks in some Eastern European countries take the form of a branch and are regulated by other countries regulatory bodies (the Bank of Italy or the Oesterreichische Nationalbank), it is a source of concern whether the maximisation of the regulator's home country objectives takes into account all important externalities on the host country. The public good provision problem arises because a pan European bank rescue appears as a public good to be financed through coordination of a number of Treasuries across Europe. This issue is considered in Freixas (2003) and in Goodhart and Schoenmaker (2006). Its implications regarding LOLR policy are that the bail-out of an institution may not be possible, simply because 
of the free riding problem. The equilibrium outcome will be more biased towards liquidation than in the case of a unique multi-country regulator.

Implementation through several regulatory bodies of the LOLR decisions implies an additional number of restrictions. It means, therefore that additional restrictions are imposed on the LOLR policy. This implies that type one and type two errors will occur, with the rescue of banks that should have been closed down and the liquidation of banks that should have been bailed out.

\section{$\underline{\text { 6. Conclusions }}$}

To conclude, it is worth to compare the classic view of the LOLR with the complexities of the above analysis, and try to summarize it by drawing the major lines of the recent advances in the contemporaneous approach of LOLR, as compared with the "wisdom of our ancestors". What is left today of the simple clear-cut guidelines suggested by Thornton and Bagehot that recommend to lend to solvent illiquid institutions against good collateral and at a penalty rate?

First, lending to the market through $\mathrm{OMO}$ is the standard way for a $\mathrm{CB}$ to prevent an aggregate liquidity shock. This is the contemporaneous version of "lending against good collateral", characteristic of developed financial markets. Yet, recent models of interbank lending teach us hat market imperfections may lead to other inefficiencies that require the LOLR support to extent beyond the pure $\mathrm{CB}$ responsibility of aggregate liquidity management and lend to individual banks, either unsecured or against collateral of lower quality, or guaranteeing their future liquidity (FPR 2000).

The second classical recommendation was to lend at a penalty. This point is now clearly controversial. In the presence of ex ante moral hazard, as in FPR (2004), a penalty provides managers with the right incentives to be diligent in their lending. Still in Rochet and Vives (2004) the recommendation is the opposite, to lend at a rate inferior of the market rate. When, in addition, we consider decentralization between several regulatory agencies, a penalty on interest rates decreases the expected cost of the LOLR loan and imposes a better discipline in banks' liquidity 
management. This will therefore make the LOLR more prone to forbearance, which, as mentioned, could either increase or decrease the efficiency of LOLR. In the case of an unbiased regulator, this will be efficient, because in case of success, the LOLR will obtain a share of the bank's profits. So, on the penalty issue there is no clear consensus yet and, hopefully, future work will help regulators to implement the efficient policy depending on the economic and financial environment.

Regarding the use of good collateral, FPR (2004) argue that this is a key feature in the intervention of the $\mathrm{CB}$. In their approach the $\mathrm{CB}$ intervenes through fully collateralized loans at a rate above the T-Bills rate, so that it encompasses a penalty, but below the interbank market rate.

The above discussion highlights the important notion that, unlike its classical predecessor, the LOLR of the twenty-first century lies at the intersection of monetary policy, supervision and regulation of the banking industry, and the organization of the interbank market. Again the recent financial markets turmoil originated with the subprime crisis of 2007 offers some insights. An accommodating monetary policy, regulatory arbitrage to save capital, and waves of financial innovations, which by definition tend to escape traditional prudential regulation, have created the conditions for slack credit standards without the rating agencies calling for adequate risk premia. The opacity of the assets of the banks and of the finance vehicles created to hold mortgages have resulted in a reappraisal of risk premia which combines with a thin market typical of the Akerlof lemons problem. Since the Summer of 2007 the CBs on both sides of the Atlantic have responded to the credit crunch with massive, coordinated, and repeated injections of liquidity - in the form of OMO, discount lending and looser collateral requirements for CB loans - with mixed results. While the LOLR interventions have succeed in avoiding defaults of major financial institutions and the spreading of systemic risk, the significant adverse selection problems in the interbank market have induced banks to hoard some of the extra liquidity instead of recycling it completely to the banks in deficit. In the end the important lesson from these events is that the LOLR can be only a partial substitute for a well functioning interbank market. Thus the issue is less to understand what rules the LOLR should follow but what architecture of prudential regulation, risk supervision, monetary 
policy, deposit insurance and ELA is best to guarantee financial stability by providing liquidity to banks. 


\section{$\underline{\text { References }}$}

Acharya, V. and Yorulmazer, T. (2007). Cash-in-the-market pricing and optimal resolution of bank failures, Review of Financial Studies, forthcoming

Allen, F. and Gale, D. (2000). Financial Contagion, Journal of Political Economy, 108, 1-33

Bagehot, W. (1873). Lombard Street: A Description of the Money Market. London: H.S. King

Blavarg U. and Nimander, P. (2002). Inter-bank exposures and systemic risk, Sveriges Riksbank. Economic Review 2, 19-45

Board of Governors of the Federal Reserve System (2002). Alternative Instruments for Open Market and Discount Window Operations. Federal Reserve System Study Group on Alternative Instruments for System Operations. Washington, D.C., December.

Bryant, J. (1980). A Model of Reserves, Bank Runs and Deposit Insurance, Journal of Banking and Finance 4, 335-44

Caballero, R.J. and Krishnamurthy, A. (2007). Collective risk management in a flight to quality episode, NBER working paper 12896, February

Calomiris, C.W. and Kahn, C. M. (1991). The Role of Demandable Debt in Structuring Optimal Banking Arrangements, American Economic Review 81, 497-513

Calomiris, C. W., Khan, C. M. and Kroszner, R.S. (1996). The Efficiency of Self-Regulated Payments Systems: Learning From the Suffolk System, Journal of Money Credit and Banking 28, part 2, 766-797

Carlsson, H. and Van Damme, E. (1993). Global Games and Equilibrium Selection, Econometrica 61, 989-1018

Castiglionesi F. (2007). Financial contagion and the role of the central bank, Journal of Banking and Finance 31, 81-101

Cifuentes R., Shin, H.S., and Ferrucci, G. (2005). Liquidity Risk and Contagion, Journal of the European Economic Association 3, 556-566

Coleman, S. P. (2002). The evolution of the Federal Reserve's Intraday Credit policies, Federal reserve Bulletin $\mathbf{8 8}, 67-84$

Dasgupta A. (2004). Financial Contagion Through Capital Connections: A Model of the origin and spread of bank panics, Journal of the European Economic Association, 2, 1049-1084

Degryse H. and Nguyen, G. (2006) Interbank Exposures: An Empirical Examination of Contagion Risk in the Belgian Banking System, Tilburg University working paper 2006-016

Diamond, D. (1984). Financial Intermediation and Delegated Monitoring, Review of Economics Studies, 51, 393-414 
Diamond, D. and Dybvig, P. (1983). Bank Runs, Deposit Insurance, and Liquidity, Journal of Political Economy, 91, 401-19

Diamond, D. and Rajan, R. (2005). Liquidity Shortages and Banking crises, The Journal of Finance, 60, 615-647

Diamond, D. and Rajan, R. (2001). Liquidity risk, liquidity creation and financial fragility: a theory of banking, Journal of Political Economy, 109, 287-327

Fisher, I. (1933). Debt Deflation theory of the great depression, Econometrica, 4, 337-357

Freixas, X. (2003). Crisis Management in Europe, in J. Kremers, Schoenmaker, D. and Wierts, P. (eds.), Financial Supervision in Europe, Cheltenham: Edward Elgar

Freixas, X., Parigi, B.M. and Rochet, J-C. (2000). Systemic Risk, Interbank Relations and Liquidity Provision by the Central Bank, Journal of Money, Credit and Banking August, 32, Part 2, 611-638

Freixas, X., Parigi, B.M. and Rochet, J-C. (2004). The Lender of Last Resort: A $21^{\text {st }}$ Century Approach, Journal of the European Economic Association, 2, 1085-1115

Freixas, X. and Jorge, J. (2007). The role of Interbank Markets in Monetary Policy: A model with rationing", Journal of Money, Credit and Banking, forthcoming.

Freixas, X. and Holthausen, C. (2005). Interbank Market Integration under Asymmetric Information, Review of Financial Studies, 18, 459-490

Friedman, M. and Schwartz, A.J. (1963). A Monetary History of the United States, 1867-1960, Princeton, NJ: Princeton University

Furfine C. H. (2003). Interbank Exposures: Quantifying the Risk of Contagion, Journal of Money Credit and Banking, 35, 111-128

Goldstein I. and Pauzner, A. (2004). Contagion of self-fulfilling crises due to diversification of investment portfolios, Journal of Economic Theory, 119, 151-183

Goldstein I. and Pauzner, A. (2005). Demand Deposit Contracts and the Probability of Bank Runs, Journal of Finance, 60, 1293-1327

Goodhart, C. A. E. (1987). Why do Banks need a Central Bank?, Oxford Economic Papers, 39, 7589

Goodhart, C. A. E. (1999). Myths about the lender of last resort, International Finance, 2, 339-360.

Goodhart, C.A.E. and Huang. H. (1999). A model of lender of last resort, IMF Working Paper $99 / 39$

Goodhart, C. A. E. and Schoenmaker, D. (1993). Institutional Separation Between Supervisory and Monetary Agencies, LSE Financial Market Group Special Paper N52.

Goodhart, C. A. E. and Schoenmaker, D. (1995). Should the functions of Monetary Policy and Bank Supervision be Separated? Oxford Economic Papers, 39, 75-89. 
Goodhart, C. A. E. and Schoenmaker, D. (2006). Burden sharing in a banking crisis in Europe, Swedish Riksbank Economic Review, 2, 34-57

Goodfriend, M. and King, R. (1988). Financial Deregulation Monetary Policy and Central Banking, in W. Haraf and Kushmeider, R. M. (eds.) Restructuring Banking and Financial Services in America, AEI Studies, 481, Lanham, Md.: UPA

Gorton, G. (1985). Clearinghouses and the Origin of Central Banking in the United States, Journal of Economic History, 2, 277-283

Gorton, G. and Huang, L. (2004). "Liquidity, Efficiency and Bank Bailouts" American Economic Review, 94, 455-483

Gorton, G. and Mullineaux, D. (1987). The Joint Production of Confidence: Endogenous Regulation and Nineteenth Century Commercial-Bank Clearinghouses, Journal of Money Credit and Banking, 4, 457-468

Humphrey, D.B., (1986). Payments Finality and risk of settlement failure. in: Saunders, A., White, L. (eds.), Technology and the Regulation of Financial Markets: Securities, Futures, and Banking. Lexington, MA: Lexington Books

Humphrey, T. (1989). The Lender of Last Resort: The Concept in History, Federal Reserve Bank of Richmond Economic Review, 75, 8-16

Ioannidou, V. P. (2005). Does monetary policy affect the central bank's role in bank supervision?, Journal of Financial Intermediation, 14, 58-85

Iyer, R. and Peydro, J.L. (2006) "Interbank Contagion: Evidence from Real Transactions", University of Amsterdam, mimeo

Kahn, C. M. and Santos, J. A. C. (2005). Allocating bank regulatory powers: Lender of last resort, deposit insurance and supervision, European Economic Review, 49, 2107-2136

Kahn, C. M. and Santos, J. A. C. (2006). Who Should Act as Lender of Last Resort? An Incomplete Contracts Model: A Comment, Journal of Money Credit and Banking, 38, 1111-1118

Kyotaki, N. and Moore, J. (1997). Credit Cycles, Journal of Political Economy, 105, 211-248

Lacker, J.M. (2004). Payment system disruptions and the federal reserve following September 11, 2001, Journal of Monetary Economics, 51, 935-965

Lehar, A. (2005). Measuring systemic risk: A risk management approach, Journal of Banking and Finance, 29, 2577-2603

Leitner, Y. (2005). Financial Network: Contagion, Commitment, and Private Sector Bailouts, Journal of Finance, 60, 2925-2953

Lybeck, T. and Morris, J.A. (2004). Central Bank Governance: A survey of Boards and Management, IMF Working Paper 04/226 
Merton, R.C. (1977). An analytic derivation of the cost of deposit insurance and loan guarantees: An application of modern option pricing theory, Journal of Banking and Finance, 1, 3-11

McAndrews J. and Potter, S. (2002). Liquidity Effects of the Events of September 11, 2001, Federal Reserve Banks of New York Economic Policy Review, November, 59-79

Mistrulli, P. (2005). Interbank lending patterns and Financial Contagion, Bank of Italy, mimeo

Morris, S. and Shin H. S. (1998). Unique Equilibrium in a Model of Self-fulfilling Currency Attacks, American Economic Review, 88, 587-597

Peek, J., Rosengren, E. and Tootell, G. (1999). Is Bank Supervision Central to Central Banking, Quarterly Journal of Economics, 114, 629-653

Peltzman, S. (1976). Toward a More General Theory or Regulation, Journal of Law and Economics, 19, 211-40

Repullo, R. (2000). Who Should act as a Lender of Last Resort? An Incomplete Contract model, Journal of Money, Credit and Banking, 32, 580-605

Rochet, J-C. and Vives, X. (2004). Coordination Failures and the Lender of Last Resort: Was Bagehot Right After All?, Journal of the European Economics Association, 2, 1116-1147

Santos, J.A.C. (2006). Insuring Banks Against Liquidity Shocks: The Role of Deposit Insurance and Lending of Last Resort, Journal of Economic Surveys, 20, 459-482

Schnabel, I. and Shin, H.S. (2004). Liquidity and Contagion: the Crisis of 1763, Journal of the European Economic Association, 2, 929-968

Shin, H.S. (2006). Risk and liquidity in a system context, Bank of international settlements Working Paper N. 212

Sprague, O.M.W. (1910). History of Crises Under the National Banking System, Philadelphia: Govt. Print. Off.

Stigler, G.J. (1971). The Theory of Economic Regulation, The Bell Journal of Economics and Management Science, 2, 3-21

Timberlake, R.H. (1978). The Origins of Central Banking in the United States, Cambridge, Mass: Harvard University Press

Timberlake, R.H. (1993). Monetary Policy in the United States, Chicago: University of Chicago Press

Thornton, H. (1802). An Enquiry into the Nature and Effects of the Paper Credit of Great Britain, London: Hatchard

Upper, C. and Worms, A. (2004). Estimating Bilateral exposures in the German interbank market: Is there a danger of contagion?, European Economic Review, 48, 827-849 
Wells S. (2004). Financial interlinkages in the United Kingdom's interbank market and the risk of contagion, Bank of England, Working Paper 230

White, E.N. (1983). The Regulation and Reform of the American Banking System, 1900-1929, Princeton, NJ: Princeton University Press 


\section{CESifo Working Paper Series}

for full list see www.cesifo-group.org/wp

(address: Poschingerstr. 5, 81679 Munich, Germany, office@cesifo.de)

2225 Walter Krämer, Long Memory with Markov-Switching GARCH, February 2008

2226 António Afonso and Christophe Rault, What do we really Know about Fiscal Sustainability in the EU? A Panel Data Diagnostic, February 2008

2227 Sergey M. Kadochnikov and Igor M. Drapkin, Market Structure, Technological Gap and Vertical Linkage Effects from Foreign Direct Investment, February 2008

2228 Guglielmo Maria Caporale, Davide Ciferri and Alessandro Girardi, Fiscal Shocks and Real Exchange Rate Dynamics: Some Evidence for Latin America, February 2008

2229 Scott Alan Carson, Geography and Insolation in $19^{\text {th }}$ Century US African-American and White Statures, February 2008

2230 Wolfgang Buchholz and Jan Schumacher, Discounting and Welfare Analysis Over Time: Choosing the $\eta$, February 2008

2231 M. Hashem Pesaran, Christoph Schleicher and Paolo Zaffaroni, Model Averaging in Risk Management with an Application to Futures Markets, February 2008

2232 Wilhelm Kohler, Offshoring: Why Do Stories Differ?, February 2008

2233 Stefan Bach, Giacomo Corneo and Viktor Steiner, Effective Taxation of Top Incomes in Germany, 1992-2002, February 2008

2234 Robert S. Chirinko, $\sigma:$ The Long And Short Of It, February 2008

2235 Volker Grossmann and Holger Strulik, Should Continued Family Firms Face Lower Taxes than other Estates?, February 2008

2236 Guido Tabellini, The Scope of Cooperation: Values and Incentives, February 2008

2237 Heinrich W. Ursprung and Christian Wiermann, Reputation, Price, and Death: An Empirical Analysis of Art Price Formation, March 2008

2238 Hans Fehr and Christian Habermann, Private Retirement Savings in Germany: The Structure of Tax Incentives and Annuitization, March 2008

2239 Joseph Francois and Ian Wooton, Market Structure and Market Access, March 2008

2240 Hiroyuki Kasahara and Beverly Lapham, Productivity and the Decision to Import and Export: Theory and Evidence, March 2008

2241 Gary E. Bolton and Axel Ockenfels, Does Laboratory Trading Mirror Behavior in Real World Markets? Fair Bargaining and Competitive Bidding on EBay, March 2008 
2242 Atsushi Oshima, B. Ravikumar and Raymond Riezman, Entrepreneurship, Organization Capital and the Evolution of the Firm, March 2008

2243 Walter Krämer and Sebastian Schich, Large-Scale Disasters and the Insurance Industry, March 2008

2244 Leif Danziger, Adjustment Costs, Inventories and Output, March 2008

2245 Anne van Aaken, Lars P. Feld and Stefan Voigt, Power over Prosecutors Corrupts Politicians: Cross Country Evidence Using a New Indicator, March 2008

2246 Hans-Christian Heinemeyer, Max-Stephan Schulze and Nikolaus Wolf, Endogenous Borders? The Effects of New Borders on Trade in Central Europe 1885-1933, March 2008

2247 Johannes Becker and Clemens Fuest, Tax Competition - Greenfield Investment versus Mergers and Acquisitions, March 2008

2248 Giorgio Bellettini and Hubert Kempf, Why not in your Backyard? On the Location and Size of a Public Facility, March 2008

2249 Jose Luis Evia, Roberto Laserna and Stergios Skaperdas, Socio-Political Conflict and Economic Performance in Bolivia, March 2008

2250 Bas Jacobs and A. Lans Bovenberg, Optimal Taxation of Human Capital and the Earnings Function, March 2008

2251 Jan-Egbert Sturm and Timo Wollmershäuser, The Stress of Having a Single Monetary Policy in Europe, March 2008

2252 Guido Schwerdt, Labor Turnover before Plant Closure: 'Leaving the Sinking Ship' vs. 'Captain Throwing Ballast Overboard', March 2008

2253 Keith E. Maskus and Shuichiro Nishioka, Development-Related Biases in Factor Productivities and the HOV Model of Trade, March 2008

2254 Jeremy Edwards and Sheilagh Ogilvie, Contract Enforcement, Institutions and Social Capital: the Maghribi Traders Reappraised, March 2008

2255 Imed Drine and Christophe Rault, Purchasing Power Parity for Developing and Developed Countries. What can we Learn from Non-Stationary Panel Data Models?, March 2008

2256 Scott Alan Carson, Health, Wealth and Inequality: a Contribution to the Debate about the Relationship between Inequality and Health, March 2008

2257 C.A.E. Goodhart, The Regulatory Response to the Financial Crisis, March 2008

2258 Stefan Bauernschuster, Oliver Falck and Stephan Heblich, The Impact of Continuous Training on a Firm's Innovations, March 2008 
2259 Michael Grimm and Stephan Klasen, Geography vs. Institutions at the Village Level, March 2008

2260 Fwu-Ranq Chang, Property Insurance, Portfolio Selection and their Interdependence, March 2008

2261 J. Atsu Amegashie and Marco Runkel, The Paradoxes of Revenge in Conflicts, March 2008

2262 Hans Jarle Kind, Marko Koethenbuerger and Guttorm Schjelderup, Efficiency Enhancing Taxation in Two-sided Markets, March 2008

2263 M. Hashem Pesaran, Til Schuermann and L. Vanessa Smith, Forecasting Economic and Financial Variables with Global VARs, March 2008

2264 Volker Grossmann, Entrepreneurial Innovation and Sustained Long-run Growth without Weak or Strong Scale Effects, March 2008

2265 Robert S. Chirinko and Huntley Schaller, The Irreversibility Premium, March 2008

2266 Andrea Galeotti and José Luis Moraga-González, Platform Intermediation in a Market for Differentiated Products, April 2008

2267 Torben M. Andersen and Michael Svarer, The Role of Workfare in Striking a Balance between Incentives and Insurance in the Labour Market, April 2008

2268 Harald Badinger, Cyclical Fiscal Policy, Output Volatility, and Economic Growth, April 2008

2269 Thomas Aronsson and Erkki Koskela, Outsourcing and Optimal Nonlinear Taxation: A Note, April 2008

2270 Gary E. Bolton, Claudia Loebbecke and Axel Ockenfels, How Social Reputation Networks Interact with Competition in Anonymous Online Trading: An Experimental Study, April 2008

2271 Nikolaus Wolf, Scylla and Charybdis. Explaining Europe's Exit from Gold, January 1928 - December 1936, April 2008

2272 Michael Funke and Marc Gronwald, The Undisclosed Renminbi Basket: Are the Markets Telling us something about where the Renminbi - US Dollar Exchange Rate is Going?, April 2008

2273 Thor Olav Thoresen and Annette Alstadsæter, Shifts in Organizational Form under a Dual Income Tax System, April 2008

2274 Helge Berger and Volker Nitsch, Too many Cooks? Committees in Monetary Policy, April 2008 
2275 Yin-Wong Cheung and Eiji Fujii, Deviations from the Law of One Price in Japan, April 2008

2276 Michael S. Michael, Sajal Lahiri and Panos Hatzipanayotou, Integrated Reforms of Indirect Taxes in the Presence of Pollution, April 2008

2277 Bas Jacobs, Is Prescott Right? Welfare State Policies and the Incentives to Work, Learn and Retire, April 2008

2278 Burkhard Heer and Alfred Maußner, Value Function Iteration as a Solution Method for the Ramsey Model, April 2008

2279 Jarko Fidrmuc and Christa Hainz, Integrating with their Feet: Cross-Border Lending at the German-Austrian Border, April 2008

2280 Kristof Dascher and Alexander Haupt, The Political Economy of Regional Integration Projects at Borders where Rich and Poor Meet: The Role of Cross-Border Shopping and Community Sorting, April 2008

2281 Katrin Assenmacher-Wesche and M. Hashem Pesaran, A VECX* Model of the Swiss Economy, April 2008

2282 Christophe Rault, Robert Sova and Ana Maria Sova, Modeling International Trade Flows between CEEC and OECD Countries, April 2008

2283 Timo Boppart, Josef Falkinger, Volker Grossmann, Ulrich Woitek and Gabriela Wüthrich, Qualifying Religion: The Role of Plural Identities for Educational Production, April 2008

2284 Armin Falk, David Huffman and W. Bentley MacLeod, Institutions and Contract Enforcement, April 2008

2285 Axel Dreher and Stefan Voigt, Does Membership in International Organizations Increase Governments' Credibility? Testing the Effects of Delegating Powers, April 2008

2286 Xavier Freixas and Bruno M. Parigi, Lender of Last Resort and Bank Closure Policy, April 2008 